\title{
ANALISIS KEARIFAN LOKAL DAN PENGEMBANGANNYA TERHADAP PARIWISATA DI KECAMATAN SUKAKARYA KOTA SABANG
}

\author{
(Analysis Of Iocal wisdom and its development to tourism in sub-district of \\ Sukakarya Sabang city)
}

\author{
Muhammad Khalis ${ }^{1}$, T. Fauzi ${ }^{1}$, Azhar ${ }^{1 *}$ \\ ${ }^{1}$ Program Studi Agribisnis, Fakultas Pertanian, Universitas Syiah Kuala
}

\begin{abstract}
Abstrak. Kearifan lokal sebagai objek dalam penelitian ini di gunakan untuk melihat dua segi yaitu segi fisik dan nonfisik, dari segi fisik meliputi makanan tradisional, cindera mata ,permainan tradisional, keahlian hidup. Segi nonfisik adalah peraturan atau norma-norma adat, seni dan budaya yang ada di kecamatan Sukakarya.Tujuan dari penelitian ini adalah untuk melestarikan nilai kearifan lokal yang ada di kota Sabang dan dikembangkan kedalam bidang pariwisata mencakup bidang ekonomi, sosial budaya, dan lingkungan. Model analisis yang digunakan yaitu model analisis deskriptif dengan pendekatan kualitatif untuk mengetahui gambaran umum mengenai kearifan lokal dan pengembangannya terhadap pariwisata di Kecamatan Sukakarya Kota Sabang. Teknik pengumpulan data menggunakan wawancara, observasi, FGD dan dokumentasi. Analisis data menggunakan model analisis interaktif dari Miles dan Huberman. Hasil dari penelitian menunjukkan bahwa . Kearifan lokal yang terdapat di kecamatan Sukakarya dari segi nonfisik berupa norma,qanun dan budaya masih terjaga dengan baik. Kearifan lokal dari segi fisik seperti makanan tradisonal sudah mulai hilang di kalangan masyarakat, ini disebabkan oleh bahan baku yang sulit didapat. Sedangkan permainan tradisional tidak lagi di mainkan oleh warga lokal karena mereka lebih tertarik dalam kegiatan pariwisata yang menghasilkan uang dan dapat menambah pendapatan mereka.
\end{abstract}

Kata kunci: Kearifan lokal, Pengembangan Pariwisata, Ekonomi, Sosial dan Budaya.

\begin{abstract}
Local wisdom as an object in this study is used to see two aspects of physical and nonphysical. in terms of physical include traditional food, souvenirs, traditional games, life skills. Non-physical aspect is the rules or norms of adat, art and culture that exist in Sukakarya district. The purpose of this study is to preserve the value of local wisdom in the city of Sabang and developed into the field of tourism covering the economic, sociocultural, and environmental. The analysis model used is descriptive analysis model with qualitative approach to know the general description of local wisdom and its development to tourism in Sukakarya district of Sabang City. Data collection techniques used interview, observation, FGD and documentation. Data analysis using interactive analysis model from Miles and Huberman. The results of the research show that. Local wisdom found in Sukakarya district in terms of nonphysical form of norms, qanun and culture is still well preserved. Local wisdom from a physical point of view such as traditional food has begun to disappear among the people, this is caused by hard-to-find raw materials, While traditional games are no longer played by locals as they are more interested in tourism activities that generate money and can supplement their income.
\end{abstract}

Keywords: Local Wisdom, Tourism Development, Economics, Social and Culture

\section{PENDAHULUAN}

Kearifan lokal adalah segala bentuk kebijakan yang didasari oleh nilai-nilai kebaikan yang dipercaya, diterapkan dan senantiasa dijaga keberlangsungannya secara turun-temurun oleh kelompok dalam lingkungan atau wilayah tertentu yang menjadi tempat tinggal mereka. Kearifan lokal terbentuk karena pola pikir 
masyarakat yang baik, perasaan mendalam terhadap tanah kelahiran, bentuk tabiat yang melekat dan dibawa saat berbaur dengan masyarakat atau lingkungan yang berbeda, filosofi hidup dan keinginan besar untuk tetap mempertahankan adat atau tradisi yang telah lama diikuti oleh generasi-generasi sebelumnya(Ahmad Baedowi, 2015)

Sektor pariwisata merupakan sektor ekonomi penting di Indonesia. Pada tahun 2009, pariwisata menempati urutan ketiga dalam hal penerimaan devisa setelah komoditi minyak dan gas bumi serta minyak kelapa sawit (Parekraf, 2014).Salah satu bentuk kegiatan rekreasi ialah mengunjungi tempat bersejarah dan gedung cagar budaya sebagai destinasi wisata.

Tabel 1. Jumlah Wisatawan Domestik dan Mancanegara yang Berkunjung ke Sabang, Tahun 2012-2016

\begin{tabular}{llll}
\hline \multirow{2}{*}{ Tahun } & \multicolumn{2}{c}{ Jumlah Wisatawan } & \multirow{2}{*}{ Total } \\
\cline { 2 - 3 } & \multicolumn{1}{c}{ Domestik } & Mancanegara & \\
\hline 2012 & 212.165 & 4.611 & 216.776 \\
2013 & 401.224 & 6.648 & 407.872 \\
2014 & 512.992 & 3.624 & 516.616 \\
2015 & 623.635 & 5.582 & 629.217 \\
2016 & 724.923 & 7.111 & 732.034 \\
\hline
\end{tabular}

Sumber: Badan Pusat Statistik Kota Sabang, 2017

Berdasarkan Tabel 1 di atas dapat dilihat bahwa jumlah wisatawan yang berkunjung ke Sabang setiap tahunnya terus meningkat, kecuali pada tahun 2014 di mana wisatawan domestik lebih banyak yang berkunjung sedangkan wisatawan mancanegara menurun. Hal ini disebabkan karena pada tahun 2014 tidak banyak terselenggaranya festival atau even internasional sehingga berpengaruh terhadap kunjungan wisatawan mancanegara. Sedangkan untuk tahun selanjutnya cenderung meningkat baik wisatawan domestik maupun mancanegara hal tersebut terjadi pemerintah setempat kembali menggelar festival yang bertaraf internasional, dinas terkait mengharapkan jumlah wisatawan yang berkunjung diharapkan dapat selalu meningkat karena dampak dari kunjungan wisatawan ini baik untuk perekonomian daerah dan negara.

Dari segi budaya pulau Sabang memiliki beragam adat istiadat yang dilahirkan oleh Multietnik. Penyebab lahirnya multietnis ini tak lepas dari masa komflik yang pernah melanda Aceh beberapa waktu lalu, sebagian masyarakat Aceh memilih untuk meninggalkan kampung halaman yang dilanda konflik untuk pergi dan mencari tempat tinggal yang aman dan banyak yang memilih untuk pergi dan menetap di Pulau Sabang karena mereka menilai di Sabang lebih aman dibandingkan kampung halaman mereka (Indra Muda, 2016).

Keinginan masyarakat dalam mengembangkan sektor pariwisata tentunya membuat masyarakat lokal harus mengikuti perkembangan global dan tanpa disadari secara langsung atau tidak langsung masyarakat lokal telah meninggalkan budaya khasnya karena tuntutan dari sektor pariwisata, sehingga banyak menimbulkan permasalahan baik itu dari sektor ekonomi, sosial budaya, dan lingkungan yang ada di tempat tujuan wisata tersebut. Adapun tujuan penelitian ini adalah: 1.Untuk mengindetifikasi bentuk kearifan lokal yang terdapat dalam masyarakat Kecamatan Sukakarya Kota Sabang. 2.Untuk mengetahui pengaruh kearifan lokal terhadap perekonomian masyarakat di Kecamatan Sukakarya Kota Sabang. 


\section{Lokasi dan Waktu Penelitian}

\section{METODE PENELITIAN}

Penelitian ini dilakukan di desa Aneuk Laot dan Iboih Kecamatan Sukakarya Kota Sabang. Penentuan lokasi penelitian ini dilakukan secara sengaja (Purposive Sampling) dengan mempertimbangkan bahwa di Kecamatan Sukakarya terdapat desa adat yang telah di resmikan oleh MAA (Majelis Adat Aceh). Penelitian ini akan dilakukan pada bulan Agustus 2017.

\section{Objek dan Ruang Lingkup Penelitian}

Objek dari penelitian ini adalah perangkat desa/gampong, masyarakat yang bergabung dalam organisasi-organisasi dan pelaku wisata yang ada di Kecamatan Sukakarya Kota Sabang. Ruang lingkup penelitian ini terbatas pada analisis kearifan lokal dan pengembangannya terhadap pariwisata di Kecamatan Sukakarya Kota Sabang.

\section{Sumber dan Metode Pengumpulan Data}

Metode yang digunakan dalam penelitian ini adalah metode survey. Menurut Nazir (2003), Metode Survey merupakan penyelidikan yang dilakukan untuk memperoleh fakta-fakta dan mencari keterangan secara faktual, baik tentang institusi sosial, ekonomi, atau politik dari suatu kelompok dalam suatu daerah. Metode pengambilan sampel dilakukan secara sengaja (Purposive Sampling). Berikut jumlah populasi dan sampel masyarakat Kecamatan Sukakarya Kota Sabang dapat dilihat pada tabel 2 berikut

Tabel 2. Jumlah Populasi dan Sampel Masyarakat Kecamatan Sukakarya Kota Sabang, Tahun 2017

\begin{tabular}{ccc}
\hline No & Uraian & Sample (orang) \\
\hline 1. & Keuchik & 2 \\
2. & Tuha Peut & 2 \\
3. & Panglima Laot & 2 \\
4. & Panglima Danau & 1 \\
5. & Ketua Jurong & 4 \\
6. & Masyarakat & 10 \\
7. & Pelaku Wisata & 9 \\
\hline Jumlah & & $\mathbf{3 0}$ \\
\hline
\end{tabular}

Sumber: Data Primer (diolah), 2017

\section{Analisis Penelitian}

Model analisis yang digunakan yaitu model analisis deskriptif dengan pendekatan kualitatif untuk mengetahui gambaran umum mengenai kearifan lokal dan pengembangannya terhadap pariwisata di Kecamatan Sukakarya Kota Sabang. Pemilihan metode kualitatif untuk memperoleh informasi dan menggali wawasan masyarakat dalam memahami keberadaan kearifan lokal tersebut (Kreno,1999).

Metode kualitatif merupakan studi mendalam menggunakan teknik pengumpulan data langsung dari lingkungan objek penelitian dan menginterpretasikan fenomena-fenomena sebagaimana adanya. Adapun analisis data dapat dilakukan sebagai berikut. 


\section{Reduksi Data}

Reduksi data adalah merangkum, memilih hal-hal yang pokok, memfokuskan pada hal-hal yang penting, dicari tema dan polanya. Dengan demikian data yang direduksi akan memberikan gambaran yang lebih jelas, dan mempermudah peneliti untuk melakukan pengumpulan data. Reduki data di gunakan untuk analisis yang menyakinkan, mengolongkan, mengarahkan dan membuang data yang di nilai tidak penting serta mengelompokkan data, sehingga memudahkan peneliti untuk menarik kesimpulan(Sugiyono, 2012).

\section{Penyajian Data}

Dalam penelitian kualitatif, penyajian dapat dilakukan dalam bentuk uraian singkat, bagan, hubungan antar katagori, flowchart dan sejenisnya Dengan mendisplaykan data diharapkan akan mempermudah peneliti untuk mengali info serta menguasai informan baik secara keseluruhan maupun bagian-bagian tertentu. Hal ini dilakukan karena data yang di peroleh belum tentu tersusun dengan baik sehingga peneliti perlu melakukan Pendisplay-an data setelah data di reduksi terlebih dahulu(Sugiyono, 2012).

\section{Penarikan Kesimpulan dan Verifikasi}

Langkah terakhir dalam menganalisis data kualitatif adalah menarik kesimpulan dan verifikasi data. Kesimpulan awal yang dikemukakan bersifat sementara, dan akan berubah bila tidak ditemukan bukti-bukti yang kuat yang mendukung pada tahap pengumpulan data berikutnya. Akan tetapi apabila kesimpulan yang dikemukakan pada tahap awal, didukung oleh bukti-bukti yang valid dan konsisten saat peneliti kembali ke lapangan mengumpulkan data, maka kesimpulan yang dikemukakan merupakan kesimpulan yang kredibel(Sugiyono, 2012).

\section{Model FGD (Focus Group Disucussion)}

Metode FGD merupakan salah satu metode pengumpulan data penelitian dengan hasil akhir memberikan data yang berasal dari hasil interaksi sejumlah partisipan suatu penelitian, seperti umumnya metode-metode pengumpulan data lainnya. Metode FGD memiliki sejumlah karakteristik, diantaranya, merupakan metode pengumpul data untuk jenis penelitian kualitatif dan data yang dihasilkan berasal dari eksplorasi interaksi sosial yang terjadi ketika proses diskusi yang dilakukan para informan yang terlibat (Lehoux, Poland, \& Daudelin, 2006). Kegiatan FGD dilakukan secara obyektif dan bersifat eksternal. FGD membutuhkan moderator untuk memfasilitasi diskusi agar interaksi yang terjadi diantara partisipan terfokus pada penyelesaian masalah.

Menurut Carey (1994) menjelaskan karakteristik pelaksanaan metode FGD, yaitu menggunakan wawancara semi struktur kepada suatu kelompok individu dengan seorang moderator yang memimpin diskusi dengan tatanan informal dan bertujuan mengumpulkan data atau informasi tentang topik isu tertentu. Metode FGD memiliki karakteristik jumlah individu yang cukup bervariasi untuk satu kelompok diskusi. Dalam penelitian ini metode FGD dan wawancara mendalam dilakukan untuk mengarahkan daftar pertanyaan yang berhubungan dengan kearifan lokal, serta alat rekam suara mendukung penulisan hasil penelitian. Berikut 
pengumpulan data dengan menggunakan metode FGD dan wawancara dapat dilihat pada tabel 3 berikut.

Tabel 3. Pengumpulan Data dengan Metode FGD dan Wawancara di Kecamatan Sukakaya Kota Sabang

\begin{tabular}{lll}
\hline Jenis data & Metode & Sumber Informasi \\
\hline & & Keuchik \\
& FGD & Tuha peut \\
Data primer & & Panglima laot \\
& & Panglima danau \\
& Wawancara & Ketua jurong \\
& Masyarakat \\
& Pelaku wisata \\
\hline
\end{tabular}

Sumber: Data Primer (diolah), 2017

Tabel 3 menunjukkan bahwa jenis data yang digunakan merupakan data primer dan metode yang digunakan adalah metode FGD dengan sumber informasi, yaitu keuchik gampong, luha peut, panglima laot, panglima danau, dan ketua jurong. Sedangkan pada metode wawancara, sumber informasinya adalah masyarakat dan pelaku wisata.

\section{Letak Geografis Dan Luas Wilayah}

\section{HASIL PENELITIAN DAN PEMBAHASAN}

Pulau Weh atau lebih dikenal dengan Pulau Sabang adalah salah satu pulau paling ujung di Provinsi Aceh, Indonesia. Pulau Sabang memiliki luas 122,14 km2 terdiri dari 2 Kecamatan dan 18 Gampong. Terletak antara 050 46'28' '- 050 54'28', Linang Utara dan 95013 '02' - 950 22'36' Bujur Timur dengan tinggi rata-rata 28 meter di atas permukaan laut. Wilayah Pulau Sabang sebelah utara berbatasan dengan Selat Malaka, sebelah selatan berbatasan dengan Selat Benggala, sebelah timur berbatasan dengan Selat Malaka, dan sebelah barat berbatasan dengan Samudera Indonesia.

Kecamatan Sukakarya merupakan salah satu kecamatan di pulau Sabang. Luas wilayah Kecamatan Sukakarya adalah $73 \mathrm{~km} 2$ dan sebesar 0,50 persen dari total luas pulau Sabang dengan ketinggian sekitar \pm 28 meter di atas permukaan laut. Secara administratif wilayah kecamatan Sukakarya berbatasan dengan Selat Malaka di sebelah utara, Samudera Indonesia di sebelah selatan, Kecamatan Sukajaya di sebelah timur dan Samudera Indonesia di sebelah barat. Mukin Iboih menjadi mukin terjauh dari pusat pemerintahan dengan jarak berkisar $20 \mathrm{~km}$.

Tabel 4. Data Geografis Kecamatan Sukakarya kota Sabang tahun 2016

\begin{tabular}{cc}
\hline Gampong & Luas Wilayah $\mathbf{( \mathbf { K m } ^ { 2 } )}$ \\
\hline Iboih & 25 \\
Bate shok & 14 \\
Paya seunara & 8 \\
Krueng raya & 6 \\
Aneuk laot & 5 \\
Kuta timu & 4 \\
Kuta barat & 4 \\
Kuta ateuh & 4 \\
\hline
\end{tabular}

Sumber: Seksi camat Sukakarya tahun 2017

Analisis Kearifan Lokal Dan Pengembangannya Terhadap Pariwisata Di Kecamatan 
Wilayah terbesar di kecamatan Sukakrya berada di Gampong Iboih memiliki luas $25 \mathrm{~km} 2$ sebagian besar wilayahnya adalah hutan lindung, jarak Gampong Iboih dengan pusat pemerintah kecamatan berkisar antara 20,0 km. Sedangkan Gampong Aneuk Laot yang Luas mencapai $5 \mathrm{~km} 2$ sebagian besar wilayah merupakan perairan di danau Aneuk laot luasnya sekitar 4 Ha. Danau Aneuk Laot sendiri menjadi sumber air di kota Sabang yang di kelola oleh PDAM Tirta Aneuk Laot Kota Sabang. jumlah daerah yang di layani mencapai 9 Gampong dengan jumlah pelanggan 4.313 pelanggan yang melayani 20,600 jiwa atau 62,5\% dari seluruh masyarakat yang ada di Kota Sabang.

Masyarakat di Kecamatan Sukakarya pada umumnya berprofesi sebagai pedagang, nelayan, petani, pegawai negeri, buruh dan wiraswata. Kecamatan Sukakarya terdiri atas 3 mukin dan 8 gampong, yang meliputi mukin sabang yang terdiri dari Gampong Kuta Ateuh, Gampong Kuta timu dan Gampong Kuta Barat. Mukin Paya Raya meliputi Gampong Aneuk Laot, Gampong Krueng Raya dan Gampong Paya Seunara sedangkan mukin Iboih, meliputi Gampong Batee Shok dan Gampong Iboih. Kecamatan Sukakarya memiliki jumlah penduduk sebanyak 15,903 jiwa memiliki data demografi sebagai berikut.

Tabel 5. Jumlah Penduduk Berdasarkan Gampong di Kecamatan Sukakarya, Kota Sabang, Tahun 2016

\begin{tabular}{llll}
\hline Gampong & Laki -laki & Perempuan & Jumlah \\
\hline Iboih & 523 & 405 & 937 \\
Bate shok & 520 & 512 & 1,032 \\
Paya seunara & 1,170 & 1,144 & 2,314 \\
Krueng raya & 678 & 715 & 1,339 \\
Aneuk laot & 513 & 428 & 995 \\
Kuta timu & 1,110 & 1,061 & 2,171 \\
Kuta barat & 1,575 & 1,567 & 3,412 \\
Kuta ateuh & 2,001 & 1,918 & 3,919 \\
\hline Jumlah total & $\mathbf{8 , 0 0 9}$ & $\mathbf{1 5 , 9 0 3}$ \\
\hline Sumber: Badan Pusat Statistik kota Sabang 2017
\end{tabular}

Dari total 15,903 jiwa jumlah penduduk yang menetap di Kecamatan Sukakrya yang dapat di kategorikan dalam usia non-produktif yaitu dari usia $>0-4$ tahun sekitar 12,5\%, usia 5-9 tahun sekitar 10,5\%, usia 10-14 tahun sekitar $8,20 \%$, dan usia yang sedang produktif $15-54$ tahun paling banyak dengan $59,15 \%$ berjumlah 9,378 jiwa sedangkan usia di atas 55 tahun menjadi paling sedikit yaitu berkisar 9,15\% dari seluruh penduduk yang berada di Kecamatan Sukakarya. Data tersebut dapat di lihat pada tabel 6 berikut.

Tabel 6. Jumlah Penduduk Berdasarkan Usia di Kecamatan Sukakarya, Kota Sabang, Tahun 2016

\begin{tabular}{lcccc}
\hline KelompokUsia & Laki- laki & Perempuan & Jumlah & Pesentase \% \\
\hline 0 - 4 Tahun & 1,049 & 935 & 1,984 & 12,5 \\
5 - 9 Tahun & 853 & 814 & 1,667 & 10,5 \\
10 - 14 Tahun & 690 & 611 & 1,301 & 8,20 \\
15 - 54 Tahun & 4,572 & 4,626 & 9,378 & 59,15 \\
$>$ 55Tahun & 755 & 768 & 1,523 & 9,15 \\
\hline Jumlah & $\mathbf{8 , 0 9 9}$ & $\mathbf{7 , 7 5 4}$ & $\mathbf{1 5 , 8 5 3}$ & $\mathbf{1 0 0 \%}$ \\
\hline
\end{tabular}

Sumber : Badan Pusat Stastistik kota Sabang 2017 
Secara umum mata pencarian penduduk di Kecamatan Sukakarya adalah sebagai nelayan dan berdagang karena sebagaian besar wilayah Sukakarya dekat dengan pantai, dan selebihnya bekerja sebagai buruh, petani, jasa, pegawai, TNI/POLRI dan lain-lainnya. Datanya dapat di lihat pada tabel 7 berikut

Tabel 7. Jumlah Penduduk Berdasarkan Pekerjaan di Kecamatan Sukakarya, Kota Sabang Tahun 2016

\begin{tabular}{lll}
\hline Pekerjaan & Jumlah & Pesentase \% \\
\hline Petani & 379 & 8,9 \\
Nelayan & 511 & 12,5 \\
Buruh & 217 & 5,1 \\
Pedagang & 621 & 14,6 \\
Jasa & 75 & 1,7 \\
Pengangkutan & 169 & 3,9 \\
Pengawai & 1,285 & 30,3 \\
TNI/POLRI & 460 & 10,8 \\
Lain-lainnya & 521 & 12,2 \\
\hline Jumlah & $\mathbf{4 , 2 1 8}$ & $\mathbf{1 0 0} \%$ \\
\hline
\end{tabular}

Sumber : Badan Pusat Stastistik 2017

Berdasarkan dari tabel di atas maka dapat di simpulkan bahwa sebagian besar penduduk di Kecamatan Sukakarya berkerja di kantor pemerintah negeri selebihnya menjadi pedagang,petani, jasa, pengangkutan dan nelayan hal ini di pengaruhi oleh letak geografis pulau yang di kelilingi oleh laut dan menjadi pulau wisata yang mudah di kunjungi oleh wisatawan domestic dan lokal.

\section{Gambaran Umum Kearifan Lokal di Kecamatan Sukakarya}

Pada pertengahan tahun 2017 Majelis Adat Aceh (MAA) Kota Sabang menetapkan salah satu gampong (desa) di kecamatan Sukakarya sebagai gampong adat percontohan. Penetapan gampong Aneuk Laot sebagai gampong percontohan di pilih berdasarkan ketentuan yang telah di sepakati oleh Dinas terkait dengan Majelis Adat Aceh. Tujuan dari dipilihnnya gampong percontohan ini adalah untuk meningkatkan peran aktif masyarakat dalam melestarikan khasanah adat istiadat Aceh yang mulai ditinggalkan oleh generasi penerus. Dengan adanya pembentukaan gampong adat percontohan tersebut diharapkan untuk dapat menghidupkan kembali peran dari tokoh adat yang ada di dalam penyelenggaraan pemerintahan, pembangunan dan pelayanan kepada masyarakat.

Dengan terpilihnya gampong Aneuk Laot sebagai gampong percontohan diharapkan dapat meningkatkan peran yang aktif serta fungsi keuchik (kepala desa) dan tokoh adat seperti tuha peut, ketua jurong, Panglima danau dan Panglima laot untuk mengayomi kehidupan masyarakat yang lebih optimal dengan meningkatkan peran serta pemerintah gampong, lembaga masyarakat dan tokoh adat yang berorientasi kepada adat dan istiadat dalam penyelenggaraan pemerintah gampong.

Penetapan gampong adat sebagai percontohan pelaksanaan khasanah adat itu juga bertujuan untuk menggali sekaligus meningkatkan kesadaran masyarakat dengan pentingnya adat dan istiadat serta peran kearifan lokal dalam kehidupan sehari-hari. Dengan memberikan dorongan serta motivasi kepada seluruh masyarakat tentang pentingnya menjaga kearifan lokal agar tidak hilang di era modrenisasi ini. Sebagai sarana edukatif, pengembangan seni dan budaya, sebagai 
sarana penggalian nilai-nilai adat istiadat, pengembangan perilaku dan budaya yang sesuai dengan perkembangan di era global ini.

\section{Kearifan Lokal di Kecamatan Sukakarya}

Gampong Aneuk laot yang ditetapkan sebagai gampong percontohan tentunya memiliki beragam jenis kearifan lokal, baik dari segi budaya, makanan, qanun, adat dan istiadatnya. Dalam kehidupan sehari - hari kearifan lokal tersebut masih di terapkan oleh masyarakat sekitar, untuk mempertahankan kearifan lokal tersebut peran dari tokoh adat gampong sangat diperluhkan, tujuannya adalah untuk melestarikan Kearifan lokal agar tidak dilupakan oleh generasi penerus.

Kearifan lokal dari segi budaya khususnya dalam kegiatan pernikahan masih terjaga di gampong Aneuk Laot, bahkan setiap acara pernikah di wajibkan semapa ketika hantaran baik dari pihak mempelai pria (tung linto) ataupun saat hantaran mempelai wanita (tung dara baro).

Adat 'Seumapa' digunakan pada acara hantaran linto atau dara baro. Adat tersebut sangat penting untuk dilestarikan mengingat generasi muda sekarang sudah jauh dari adat dan syariat yang ada di Aceh. 'Seumapa" merupakan seni Tutur yang menyuguhkan nilai adat Aceh di samping pesan yang terkandung didalamnya dengan berseni Tutur (balas pantun) berupa nilai edukasi dan nasehat-nasehat yang indah untuk kedua mempelai. Indahnya 'Seumapa" juga, karena dalam kegiatan adat ini, membutuhkan kreatifitas berbahasa dalam sapa menyapa serta membutuhkan daya nalar dan kreatifitas tinggi, disini dituntut bahasa yang cepat dan kreatif, karena setiap daerah tentu punya kekhasan masing-masing dan bahasa seumapa juga harus disesuaikan dengan tempat dan kondisi suatu daerah di Aceh.(Termizi hamid 2017).

\section{Makanan Tradisional}

Makanan tradisional dapat dijadikan sebagai suatu wisata kuliner yang dapat mengangkat citra dari suatu daerah. Ketika wisatawan yang berkunjung ke Sabang tentunya mereka dengan mudah menemukan toko-toko atau rumah makan yang menyediakan makanan dan kue khas Sabang.

Kelompok Bunong Jaroe yang berada di gampong Aneuk laot sudah lama ini menjadi home industry yang memproduksi kue-kue tradisonal khas Aceh baik itu untuk hantaran acara pernikahan maupun untuk oleh-oleh yang dijadikan buah tangan ketika berkunjung ke Sabang. kelompok bungong jaroe merupakan satusatunya kelompok yang menyediakan kue hantaran untuk acara pernikahan. Khusus untuk kue hantaran ketua kelompok menjelaskan bahwa pemesanan haru dilakukan minimal tiga hari sebelum acara, ini di karena proses pembuatan yang tergolong sulit dan membutuhkan anggota pekerja yang lebih banyak, berbeda dengan kue seperti kekara dan kue kacang ijo yang pembuatannya tidak membutuhkan banyak pekerja.

Makanan tradisional khas dari gampong Iboih tersebut tidak bisa di kembangkan kedalam sektor pariwisata pantai Iboih, ini di karenakan proses pembuatan yang rumit dan bahan baku yang menggunakan rempah-rempah susah di dapat sehingga tidak bisa di sediakan oleh rumah makan yang berada di pantai Iboih. Sedangkan untuk untuk jenis masakan leubim panggang dan yee tepeuaweuh yang menggunakan bahan utama ikan Pari dan ikan Hiu juga tidak disediakan 
karena ikan Pari dan ikan Hiu termasuk dalam hewan yang dilindungi oleh hukum dan tidak bisa di tangkap.

\section{Cinderamata}

Salah satu tujuan wisatawan berkunjung ke daerah tujuan wisata (DTW) adalah untuk berbelanja kebutuhan pribadi dan mendapatkan oleh-oleh atau cinderamata yang khas dari wilayah tersebut untuk dibawa pulang sebagai kenangkenangan bagi wisatawan tersebut. Cinderamata terbukti menjadi sarana yang sangat efektif untuk mengenalkan daerah tujuan wisata, umumnya di seluruh tempat wisata menyediakan cinderamata baik itu dalam bentuk baju, kain, gantungan kunci, dan miniature yang mengambarkan daerah tersebut.

Sebagian tempat wisata yang menjadi daerah tujuan wisata (DTW) menyediakan berbagai cinderamata yang berasal dari wilayah itu sendiri. Sedangkan, sebagian wilayah lainnya mendapat berbagai jenis cinderamata dari luar daerah untuk memenuhi keinginan dari wisatawan. Ini terjadi karena tidak adanya warga yang memiliki keahlian dalam membuat cindera mata dan terbatasnya bahan baku yang bisa di olah menjadi cineramata tersebut.

Kurangnya peran dari pemerintah dalam memberdayaan masyarakat lokal untuk diberi pelatihan. Pelatihan yang dimaksud adalah pelatihan khusus dalam mengolah poduk mentah menjadi kerajinan tangan, sehingga dapat di jadikan cinderamata oleh wisatawan baik lokal maupun mancanegara yang berkunjung ke Sabang.

\section{Permainan Tradisional}

Permainan tradisional merupakan permainan yang umumnya dimainkan oleh anak-anak kecil dan remaja untuk mengisi waktu kosong mereka. Permainan tradisional biasanya di mainkan pada lapangan terbuka dan di pinggir pantai, biasa ketika anak-anak memainkan permainan tradisional masyarakat setempat akan berkumpul untuk menonton dan meramaikan suasana di lapangan. Namum di era globalisasi sekarang permainan tradisional mulai di tinggalkan oleh anak-anak, hal ini terjadi karena mereka lebih suka dengan permainan game online yang di sediakan oleh warnet dan sebagaian game online bisa di akses dengan telpon seluler.

Permainan tradisional yang telah hilang adalah tak galah, permainan di tinggalkan karena permainan tersebut jarang dimainkan dan generasi penerus tidak kenal lagi dengan permainan tersebut, permainan ini sudah lama hilang di kalangan masyarakat Iboih. Sedangkan untuk permainan layang-layang masih di mainkan oleh masyarakat gampong Iboih, permainan tersebut sering di perlombangankan oleh masyarakat dan sekarang sudah termasuk dalam event tahunan, penyelenggaraannya melibatkan hampir seluruh masyarakat di Sabang sehingga event ini juga bisa dinikmati oleh para wisatawan.

\section{Seni dan Budaya}

Seni dan budaya sangat berpengaruh dalam kegiatan pariwisata, budaya mencerminkan keadaan sosial dan alam suatu wilayah yang akan menjadi destinasi pariwisata. Perkembangan pariwisata berpengaruh positif dan signifikan terhadap budaya lokal, dimana terlihat pada pariwisata dapat memacu motivasi kreativitas seni para pematung untuk berkarya lebih inovatif dan lebih variatif sesuai dengan 
kebutuhan pariwisata dan meningkatnya persaingan bisnis, Dapat mengetahui budaya dari berbagai negara terutama melalui berbagai pesanan karya seni selain yang di hasilkan oleh masyarakat lokal.

Gampong Aneuk laot menyelenggarakan acara pernikahan, hajatan dan memperingati hari besar agama hiburan yang di perbolehkan hanya tarian seudati, ranub lampuan, rebana dan laski (seni kasidah). Ketetapan tersebut di pilih karena toko adat menilai jika acara pernikahan atau hanjatan menggunakan biduan untuk menghibur dapat merusak citra dan tidak cocok dengan budaya lokal. Pemerintah setempat juga menyediakan peralatan musik untuk lembaga seni gampong, penyediaan alat musik tersebut diharapkan dapat membantu lembaga seni dan dapat dipergunakan ketika ada acara yang di selenggarakan.

\section{Aturan atau norma-norma (qanun)}

Di gampong Aneuk laot terdapat norma atau qanun yang di tetapkan oleh tokoh adat Panglima danau untuk menjaga danau Aneuk laot. Tujuan dari penetapan qanun tersebut adalah untuk menjaga kelestarian danau Aneuk laot agar tidak tercemar dari sampah yang di buang oleh masyarakat dan penggunaan alat tangkap ikan yang berbahaya seperti meracun serta menggun akan alat peledak. Tindakan tersebut sangat dilarang di danau Aneuk laot.

Menurut ketentuan qanum yang telah disepakati oleh Panglima danau dan masyarakat jika terdapat warga yang melanggar ketentuan yang telah di sepakati akan di denda sebesar Rp 5.000.000 untuk pelaku dan hadiah sebesar Rp 1.000.000 untuk warga yang menangkap. Cara ini dianggap mampu mencengah warga dari melakukan pencemaran air danau Aneuk Laot. Untuk pelaku yang melanggar tidak selalu di denda dengan membayar uang ada ketentuan mereka diharuskan membersihkan menasah dan gampong dimana dia melanggarnya.

Selain itu tokoh adat yang berada di gampong Aneuk laot sedang merancang beberapa qanun mulai dari mengatur tatanan pemerintah di gampong, dan penetapan festival-festival budaya. Tujuan dari perencanaan qanun tersebut adalah untuk membuat gampong Aneuk laot lebih tertata dengan model Kearifan lokal mengingat gampong tersebut sudah di tetapkan sebagai gampong percontohan di kecamatan Sukakarya.

Sedangkan untuk gampong Iboih yang telah lebih dulu dikenal dengan wisata baharinya juga memiliki norma-norma yang masih terjaga dengan baik, salah satunya ketika ada masyarakat setempat yang meninggal maka seluruh kegiatan wisata di berhentikan tanpa terkecuali. Ini merupakan norma yang telah lama dijalankan oleh masyarakat yang berada di Sabang khususnya gampong Iboih.

Larangan melakukan kegiatan pariwisata tidak hanya diberlakukan pada saat ada warga yang meninggal saja, akan tetapi pada saat acara adat seperti kanduri laot, bulan ramadhan dan sebelum siap shalat jum'at juga dilarang melakukan kegiatan di tempat wisata. Jika terdapat warga yang melanggar maka akan di beri sanksi adat oleh tokoh masyarakat setempat, hukuman terberat yang diberikan adalah di usir dari gampong tersebut.

\section{Kearifan Lokal Terhadap Ekonomi}

Kegiatan pariwisata pun mampu memperbaiki perekonomian masyarakat secara langsung, karena pelaku wisata menyediakan jasa untuk wisatawan yang berkunjung ke pantai Iboih, semakin terkenalnya tempat wisata maka semakin besar 
pula pendapatan yang akan di dapat oleh pelaku wisata. Di lihat dari segi lain, masalah baru juga timbul dimana daerah yang terkenal dengan destinasi wisatanya akan mengundang warga di sekitar bahkan dari daerah lain untuk membuka tempat usahanya. Sehingga terjadi persaingan di dalam tempat wisata tersebut. Permasalah ini belum sepenuhnya dapat di selesaikan.

Masalah lain ketika tempat wisata sudah berjalan yaitu tempat usaha dijalankan secara tidak professional, dan hampir sebagaian besar tempat usaha penyewaan boat dan alat snokling yang ada di pantai Iboih kurang perawatan dan sebagian alat yang di gunakan untuk menyelam hanya di rawat seadanya, masalah lainnya adalah ketika wisatawan menyeberang ke pulau Rubiah dengan boat penyewaan mereka tidak dilindunginya oleh asuransi. Masih sedikit tempat usaha yang ada di pantai Iboih di jalankan secara professional, hanya beberapa tempat usaha yang di jalankan secara professional namum tempat tersebut di kelola oleh warga asing bukan masyarakat lokal.

Dalam menjalankan kegiatan pariwisata peran dari agen pariwisata sangat penting, selain menjadi tourgate yang mengarahkan perjalanan dan memberikan info destinasi tujuan wisata, mereka juga menjadi juru bicara ketika wisatawan asing berinteraksi dengan masyarakat lokal. Agen sering di cari oleh wisatawan ketika berkunjung ke Sabang sehingga sebagian masyarakat memilih menjadi agen. Namum masyarakat yang memiliki peran sebagai agen perjalanan wisata belum memahami sepenuhnya bagaimana peran agen tersebut. Sehingga wisatawan belum bisa menikmati perjalanan wisatanya secara penuh ketika berkunjung ke Sabang

\section{Kearifan Lokal Terhadap Sosial Budaya}

Dampak kegiatan pariwisata terhadap sosial dan budaya tidak selalu buruk dan negatif. Dalam hal ini sangat tergantung kearifan pelaku budaya, pemerintah, dan pelaku wisata menyikapinya. (Pitana 1999) sisi positif kegiatan pariwisata dilihat secara sosial budaya adalah terjadinya cultural inovation, conservation, penguatan ikatan tradisional, dan mendorong kreatifitas. Budaya yang di bawa oleh wisatawan mancanegara cenderung tidak sama dengan budaya lokal yang ada di Sabang. Namum tidak semua budaya luar yang dibawa berdampak negatif ada juga yang berdampak positif bagi masyarakat lokal.

Wisatawan asing yang ingin melakukan pesta ketika berwisata ke pantai Iboih tetap di bolehkan akan tetapi mereka harus mematuhi paraturan lokal dimana pesta hanya boleh di gelar sampai jam 11 malam. Hal ini menjelaskan bahwa budaya luar masih bisa di jalankan dan tidak menganggu masyarakat dengan catatan mereka menghormati budaya lokal dengan menghentikan kegiatan sebelum tengah malam. Jika wisatawan tidak mematuhi peraturan tersebut maka acara pesta yang diselenggarakan akan di bubarkan oleh masyarakat, karena telah melanggar peraturan yang telah di tetapkan oleh pemerintah setempat.

\section{Kearifan Lokal Terhadap Lingkungan}

Kegiatan pariwisata selalu melahirkan masalah baru terhadap lingkungan sekitarnya, masalah yang di sebabkan tidak lain karena pengembangan dari kegiatan pariwisata itu sendiri. Dampak langsung bisa dilihat dari perubahan lingkungan alam sekitar, salah satu penyebabnya adalah pembangunan hotel,penginapan dan homestay untuk peristirahatan wisatawan. Dampak lain terhadap lingkungan yaitu bertambahnya sampah plastik dan botol bekas pakai 
yang dapat menyebabkan lingkungan sekitar jadi tercemar. Sampah sudah lama menjadi masalah dalam kegiatan pariwisata, sampai sekarang belum dapat di tanggani dengan baik oleh dinas terkait.

Kecamatan Sukakarya yang merupakan penyedia sumber air untuk sebagian besar pulau Sabang tentu perlu menjaga kualitas air dari danau Laut tawar agar tidak tercemar dan bisa tetap di komsumsi. Untuk mengatasi masalah tersebut masyarakat di sekitar danau Laut tawar membuat tim khusus yang menjaga dan mengawasi kegiatan di danau Laot tawar."Dari segi lingkungan masyarakat sudah menciptakan tim pahlawan peduli lingkungan".(F A, 22 Agustus 2017).

Dengan hadirnya pahlawan peduli lingkungan tentunya sangat berpengaruh dalam menjaga lingkungan agar selalu terjaga dan tidak tercemar oleh sampah sisa dari kegiatan wisatawan. Kehadiran pahlawan peduli lingkungan ini di harapkan dapat mengatasi permasalahan dari sampah dan diharapkan para pelaku ikut membantu mereka dalam mengatasi permasalah sampah tersebut.

\section{Pengembangan Pariwisata di Kecamatan Sukakarya}

Kecamatan Sukakarya belum sepenuhnya mengembangkan kegiatan pariwisata yang berkelanjutan sehingga menimbulkan masalah seperti kebersihan, keamanan, dan kejenuhan pariwisata, kejenuhan pariwisata terjadi karena destinasi yang di kunjungi tidak di kembangan dengan optimal sehingga wisatawan bosan dengan destinasi wisata tersebut. Permasalahan ini sering menjadi ancaman ditempat wisata apabila tidak dikembangkan secara berkelanjutan. Untuk mencegah permasalah tersebut pelaku wisata di Kecamatan Sukakarya di bantu oleh dinas kepariwisataan berencana menyelenggarakan festival-festival yang berskala nasional dan internasional. Tujuan di selenggarakan festival-festival tersebut adalah untuk menambah minat dari wisatawan yang berkunjung ke Sabang, karena selama ini wisatawan domestik dan mancanegara hanya menikmati wisata bahari. Dengan demikian destinasi yang di kunjungi ketika berada di Sabang menjadi lebih bervariasi tidak hanya dari sektor bahari akan tetapi dari sektor budaya menjadi destinasi baru di kota Sabang.

\section{Simpulan}

\section{SIMPULAN DAN SARAN}

Berdasarkan dari hasil penelitian yang dilakukan di Kecamatan Sukakarya Kota Sabang dapat di simpulkan sebagai berikut:

1. Kearifan lokal yang terdapat di Kecamatan Sukakarya dari segi nonfisik berupa (norma qanun dan budaya) masih terjaga dengan baik. Selain itu kearifan lokal budaya dari adat dan istiadat akan dikembangkan dalam sektor pariwisata melalui festival-festival budaya salah satunya acara pernikahan yang menyediakan adat semapa (berbalas pantun) ketika hantaran pernikahan (intat linto dan tung dara baro). Kearifan lokal dari segi fisik seperti makanan tradisonal sudah mulai hilang dikalangan masyarakat, hal ini dipengaruhi oleh bahan baku yang sulit didapat untuk membuat makanan tradisonal. Selain itu warga yang memahami tentang proses pembuatan makanan tradisional sudah mulai jarang yang mengerti sepenuhnya, sehingga tidak ada generasi penerusnya. Sedangkan untuk permainan tradisional juga tidak lagi dimainkan oleh warga lokal karena mereka lebih tertarik dalam kegiatan pariwisata yang menghasilkan uang dan dapat menambah pendapatan mereka. 
2. Pengaruh dari wisatawan asing yang berkunjung di Kecamatan Sukakarya dilihat dari segi budaya lokal tidak berdampak buruk, ini dikarenakan masyarakat tidak mempermasalahkan budaya luar yang hadir ketika turis berkunjung, masyarakat lokal hanya melihat dampak pariwisata dari segi perekonomian, dengan hadirnya wisatawan lokal maupun mancanegara tentunya membuka lahan pekerjaan untuk masyaraka sekitar. Dari segi ekonomi kearifan lokal yang ada di pantai Iboih berperan dengan baik, karena masyarakat Gampong Iboih dapat di berdayakan dengan memanfaatkan lahan usaha yang ada di pantai Iboih, masyarakat Gampong Iboih sudah 97\% terlibat langsung dalam kegiatan wisata sedangkan 3\% terlibat secara tidak langsung. Sedangkan peran kearifan lokal dari segi lingkungan juga sudah baik karena telah menciptakan tim pahlawan lingkungan yang bertugas menjaga kebersihan dan melapor jika terdapat masyarakat atau wisatawan yang merusak lingkungan ataupun yang membuang sampah sembarangan sehingga berdampak buruk untuk lingkungan wisata.

\section{Saran}

Berdasarkan dari kesimpulan-kesimpulan yang telah diuraikan di atas maka penulis mengambil saran sebagai berikut:

1. Diperluhkan pemberdayaan terhadap tokoh-tokoh adat yang ada di Kecamatan Sukakarya agar kearifan lokal yang terdapat di tempat tersebut dapat dilestarikan dan tidak hilang di masa yang akan datang.

2. Pemerintah diharapkan dapat mendukung sepenuhnya dalam program pembinaan untuk masyarakat lokal. Selama ini masyarakat di Gampong Iboih tidak mendapatkan pelatihan secara khusus dalam membuat souvenir.

3. Pengembangan pariwisata yang berkelanjutan diharapkan bukan hanya sekedar wacana dari pemerintah dan pelaku wisata akan tetapi dapat diaplikasikan dengan benar, minimal dalam program penyadaran masyarakat akan pentingnya menjaga lingkungan alam, khususnya lingkungan bahari yang menjadi tujuan dari wisatawan.

\section{DAFTAR PUSTAKA}

Adiwarman A. Karim. 2008. Ekonomi Makro Islam. PT. Raja Grafindo Persada, Jakarta

Adirozal, 2001. "Budaya Lokal dalam Konteks Budaya Global: Eksistensi Kesenian Tradisional dalam Industri Pariwisata" dalam Jurnal Eksperisi Seni, 1 September, STSI Padang panjang.

Aini Mufidah, 2017, "Pengembangan Integrasi Sosial Melalui Kearifan Lokal (Suku Jawa dan Suku Bali di Kampung Rama Utama Kecamatan Seputih Raman Kabupaten Lampung Tengah”, Jurnal Kearifan Lokal 5 (9) : 17.

Anita Sulistyaning Gunawan, dkk. 2016. "Analisis Pengembangan Parawisata Sosial Ekonomi Masyarakat (studi pada wisata religi gereja pusarang kediri)", Jurnal Administrasi Bisnis. 32 (1) : 10.

Ardi Surwiyanta. 2003. Dampak Pengembangan Pariwisata Terhadap Sosial Budaya dan Ekonomi. Jurnal Media Wisata 2 (1) : 20.

Busron A. Karim. 2010. Pariwisata; Antara Tuntunan Industri Dan Kearifan Lokal. Jurnal KARSA, 18(2) : 157. 
Ditjen Pengembangan Destinasi Pariwisata, Departemen Kebudayaan dan Pariwisata dan WWF Indonesia. 2009. Prinsip dan Kriteria Ekowisata Berbasis Masyarakat. Jakarta: Departemen Kebudayaan dan Pariwisata dan WWF Indonesia.

Djamhur Hamid. 2016. Dampak Pengembangan Pariwisata Terhadap Kehidupan Masyarakat Lokal Di Kawasan Wisata Studi Pada Masyarakat Sekitar Wisata Wendit, Kabupaten Malang. Jurnal Adminitrasi Bisnis (JAB) 30 (1) : 16.

Fatmawati, Malik. 2016. Peranan Kabudayaan Dalam Pencitraan Kebudayaan Bali. Jurnal Kepariwisataan Indonesia 11(1) : 19.

Gulo, W. 2002. Metode Penelitian. PT. Grasindo, Jakarta

I Gusti Made Wendri. 2016. Kajian Motivasi: Penawaran Pariwisata Spiritual Bali Ke Depan. Jurusan Pariwisata Negeri Bali. Jurnal Sosial dan Humaniora, 6(1) : 19.

I Putu Gede Parma. 2010. Kontribusi Pariwisata Alternatif Dalam Kaitannya Dengan Kearifan Lokal Dan Keberlansungan Lingkungan Alam. Diterbitkan Pada Jurnal Media Komunikasi FIS Universitas Pendidikan Ganesha Edisi Khusus Perhotelan 9(2) :45-57.

Jessy, Tiara Apriani Putri. "Strategi Peningkatan Pendapatan Asli Daerah (PAD) Kota Balikpapan Melalui Pajak Daerah Sektor Pariwisata". Journal Administrasi Negara. 5 (3) : 45-60.

Karisma, Widya \& Abiding lating. "Analisis Peran Industri Pariwisata Terhadap Pendapatan Asli Daerah Kabupaten Wonosobo. Jurnal Ilmiah FEB Unibraw Kharisma. 1 (3) : 34-40

Khairani. 2009. Analisis Variabel Yang Berpengaruh Terhadap Pembentukan Citra Daerah Tujuan Wisata : Studi Kasus Wisatawan Nusantara Yang Berwisata Ke Yogyakarta Periode 2007-2009. Skripsi. Universitas Indonesia.

Lilian Sarah." Dampak Pariwisata Terhadap Pendapatan Dan Tingkat Kesejahteraan Pelaku Usaha Di Kawasan Wisata Pantai Natseda, Pulau Ambon". Jurnal Organisasi dan Manajemen, 9 (1) :87-105.

Luthfi, Muhammad. "Pengembangan Pariwisata dan Dampak Sosial Ekonomi di Bandar Lampung".Jurnal Riset Akuntansi dan Manjemen. Vol.2 No.1. (Juni, 2013).

Mohd Jirey Kumalah. 2015, “Kearifan Tempatan Dan Potensinya Sebagai Tarikan Pelancongan Berasaskan Komuniti: Kajian Kes Komuniti Bajau Ubian Di Pulau Mantanani, Sabah", Malaysian Journal of Society and space 11 (12) : 112-128.

Moleong, 2010. Metodelogi Penelitian Kualitatif Edisi Revisi. Remaja Rosda Karya, Bandung.

Nurhadi, Febrianti Dwi Cahya.el. "Strategi Pengembangan Pariwisata Oleh Pemerintah Daerah Terhadap Pendapatan Asli Daerah" (Studi Pada Dinas Pemuda, Olahraga, Kebudayaan, dan Pariwisata Kabupaten Mojokerto). Jurnal Administrasi Publik (JAP). 2 (2) : 27-40.

Pawarti, A., H. 2012. "Nilai pelestarian lingkungan dalam kearifan lokal lubuk larangan ngalau agung di kampuang surau kabupaten dharmaraya provinsi sumatera barat". Prosiding Seminar Nasional Pengelolaan Sumberdaya Alam Dan Lingkungan. 
Pitana, I. G., \& Diarta, I. k. (2009). Pengatar Ilmu Pariwisata. Yogjakarta: penerbit Andi.

Sibarani, 2012. Kearifan Lokal: Hakikat, Peran, dan Metode Tradisi Lisan. Jakarta: asosiasi Tradisi Lisan.

Sugioyono, 2012. Metode Penelitian Kuantitatif Kualitatif dan $R \& D$. Alfabeta, Bandung.

Suryadana, M Liga dan Vanny Octavia. Pengantar Pemasaran Pariwisata. Bandung: Alfabeta. 2015.

Undang-Undang Republik Indonesia Nomor 9 Tahun 1990 Tentang Kepariwisataan. Jakarta : Sekreteriat Negara.

Wanjat Kastolani. Sri Marhanah dkk. 2016. Hubungan Daya Tarik Wisata Dengan Motivasi Berkunjung Wisatawan Ke Alam Wisata Cimahi. Jurnal Manajemen Resort dan Luisure. 13 (1): 25-30. 